\title{
The Validation of Undergraduate Student Theses of Geography Education Department, Faculty of Social Science, Universitas Negeri Malang
}

\author{
Y. Suharto \\ Geography Department, Faculty of Social Science, \\ Universitas Negeri Malang \\ Malang, 65145, INDONESIA \\ yusuf.suharto.fis@um.ac.id
}

\begin{abstract}
The aim of the research is to study the content validity and the Indonesian language composition of undergraduate student theses of Geography Education Department, Faculty of Social Science State University of Malang (UM) which were written in 2011 to 2013. The limitation to three years is based on the assumptions that the themes of the theses are still "in" as student theses' hot issues in the following ten years. At the same time, this study might focus on the Indonesian language composition, too, in order to have better student's writings. The purpose of the validation is to avoid the same mistakes made by the students in the next ten years, in terms of both the content and the composition. The method of the research is the content analysis and it uses two validation instrument, they are the columns of content validity and of the standard Indonesian language composition criterion. The result of the research is; first, the content weakness of the thesis on correspondence aspect and the rationalization of the result of the research; and second, the language composition weakness in delivering messages which were not formulated as standardized Indonesian composition rules yet. Other research findings are; first, students preferred to finish their thesis on the short term semester; second, they preferred to do non experimental research-classroom action research-and experiment research, and third, there were some indications that the scoring of the theses assessment were not consistent.
\end{abstract}

Keywords-faculty of social science; geography education; theses; validation

\section{INTRODUCTION}

The reason the theses analysis needs to be done is as another alternative to have a better quality of scientific works of the students. The argumentation that this action might be executed is that, first, there has been a thought for long that the control of the quality of student's theses in terms of the content and writing system have only been done when those were brought to the examiner's desk, and second, the examination lasted 90 minutes approximately, and the duration was suspected to be too short to discuss the content of the theses in detail. Syafi'ie (1984) already proved that there are still so many hidden mistakes that "are left untouched" during the examining process and the revising process of the student's theses.

This analysis is focused on the student's theses of Geography Department, Faculty of Social Science, UM across the year of 2011 to 2013. The limitation of the writing year is based on the argumentations that the theses, which were written during those years, were still relevant to be used as a written reference for the next ten years. If the content and/or the language composition of the theses are not analyzed carefully, it could be predicted that the following student's products will result the same quality as the previous ones.

Through the documentary note-taking to several student products, it was found two major mistakes in content and composition. The mistake patterns of the language compositions are; the mistake in the process of copying some portions, the incapability in using the supra segmental marks, the mistake in determining the standard vocabularies, the structure of the sentences, the construction of the paragraphs. The mistake patterns of the content are; the background does not focus on the problem, the statements of the problems are not stated in points, the composing of some theories does not direct to the reinforcement of the research assumptions, the method selected is not reinforced by theoretical argumentations, the data explanation is not easy to understand, there is no appropriate verification in discussion, and the conclusion and suggestion do not highlight the main findings of the research and drawn in too many complex words.

Besides the problem in content and composition, in the more deeply note-taking, it was found the tendency of plagiarism cases. There are some types of the plagiarism found. The highest level of plagiarism was represented by the same topics with their operational definitions and..., the lower level of plagiarism was shown by the use of the same references. The patterns of plagiarism are: simply copying some portion of literature, regardless the rules of how to quote others' theory correctly and taking off the platitude discussion and conclusion of the paragraphs from the previous phases and put into their theses.

Based on the facts that has been found in the documentary note-taking activity towards some previous theses written by the students during previous three years, it was formulated the aims of the research are stated as follows: 1) How is the content validity of the theses of the Geography Education Department students, Faculty of Social Science UM produced in the year 2011 to 2013 ? And 2) How is the composition validity of the theses of the Geography Education Department students, Faculty of Social Science UM in the year 2011 to 2013 ? 


\section{METHOD}

This research is classified as a library research, which examine the theses as the library documents. The method that will be applied is a content analysis method. The steps to do this research are divided into five steps, they are documentary note-taking, categorizing the document, validating, scoring, and making conclusions.

The theses used as the source of the data is taken out from five categories, they are: those of the development research, library research (text books), classroom research, non-experimental research, and experiment research. From each category, then, it has been chosen three theses as samples. All three samples of each category are taken from the piles of collecting theses that have an academic grade point which are equivalent to B. These theses are assumed to have more mistakes than the theses with grade $\mathrm{B}+, \mathrm{A}$ - or $\mathrm{A}$. The mistake patterns that were found in the documents can be used to inspect the mistake patterns of the higher grade documents.

The analysis of the documents is seen from two substances, the first is its language composition. Because the theses are written in Bahasa Indonesia, therefore, the analysis might be based on the Perfected Indonesian Orthography (Ejaan Bahasa Indonesia yang disempurnakan, EYD), including the spellings, grammars and vocabularies. And the second substance is its content, which will be measured and defined according to the scientific principle of propriety, as written in the methodology point of view. The propriety criteria of those measuring standards are reduced and synthesized to be a thesis analysis instrument, named "scoring and criterion column".

The analysis techniques that are used are textual analysis and descriptive analysis. The textual analysis is used by comparing the result of the identification of content or language composition mistakes, then scoring the mistake level. Descriptive analysis is needed to process the mistake level score, the language composition and the theses content

\section{RESEARCH FINDING}

\section{A. General Description of the Characteristic and the Theses Quality}

The submitted theses of Undergraduate Student of Geography Education Department, Faculty of Social Science, UM in year 2013 are 385 documents. Of that number it was divided into $26.33 \%$ of documents in odd semester, $45.67 \%$ in even semester and $56.33 \%$ in the short term semester. It is approximately equal to the ratio of $1: 2: 3$. This finding shows that students preferred to write the theses in the short term semester, and this tendency happens consistently.

The student interests in choosing the kinds of the research of their theses vary in every year. In this research the kinds of the research are divided into five groups, they are: developing research, library research, classroom action research, non-experimental research and experimental research. The analysis result shows that the average number of documents for each kind of the research is: experimental research are 21.33 documents, non-experimental research are 52.33 documents, and library research are 5.00 documents, classroom action research are 43.67 documents, development research are
3.00 documents. If they are put in simple ratio, they equal to $7: 7: 2: 14: 1$.

Those analysis findings show that the students prefer to have non-experimental research as the most favorable kind of research, the alternate kinds of research are following: classroom action research and experimental research. Library research is the kind of research that only few students choose and the last alternative one is developing research. From the statistics, those preferences are "convinced" always to happen consistently from semester to semester. But, in the near future, if a new policy "forbids" the students of the Geography Education Department to do any research, but an educational research, the students are predicted to do classroom action research or learning model experiment research as their favorite kinds of researches.

The student theses quality is represented by the grade given by the examiners, and they are documented in the grade recapitulation in the department. The data recapitulation shows that the number of the student theses across the year are those with grade A- . There is a gaffe by that explanation that almost all theses in 2012/2013 are close to perfect. When it is compared to the theses in 2010/2011 and 2011/2012, those data are up and down (raising drastically). The fluctuation showed the inconsistency indication in grading the theses quality.

The analysis of the inconsistent grading is examined by comparing the grade given by the examiners and the validation results, and it shows that the grading is far from being consistent. Among the five kinds of the researches only experiment research is more consistent. The comparing grades given by the examiners and the validation result do not show wide gap. The grades B, Aand $\mathrm{A}$ are relevant to the level of content mistakes found in the theses.

\section{B. The Analysis Findings of Language Composition Aspect and Content}

The analysis towards three experiment research theses written by: ATW (2011) with grade B+, APW (2013) with a grade A-, and IS (2013) with a grade A can be seen as follows:

Data 1 shows that a relatively high level of mistakes is found in the theses of experimental research. The mistakes made are found in the background, the theories, finding descriptions and the discussion. Data 2 shows that the language composition aspects in experimental research these are good, except the paragraph structure. The general patterns of the mistakes in the paragraph structures are: the unclear mind idea in the paragraphs, no relevant declarative sentences to their main idea and the length of the declarative sentences is not consistent. They are sometimes written too long while others are too short in a single paragraph.

The analysis towards three non-experimental research theses written by: LYI (2011) with grade A, SAP (2012) with grade A+, and YP (2013) with grade B can be seen as follows:

Data 3 shows two cases. First, the indication of inconsistency in grading the quality of non-experimental research theses and second, a high level of mistakes in all aspects, and it goes to be fatal. Data 4 also shows two cases. First, the indication of inconsistency in grading and 
second, higher level of mistakes found in aspect distribution. This could be happening because of inaccurate grading. Sample with grade B has almost the same mistakes as the above sample with grade A. And the language composition aspects that have high levels of mistakes are the correct use of punctuations and the paragraph structure.

The analysis towards the classroom action research theses is applied on three samples of documents, they are written by: IDA (2011) with grade B, AB (2012) with grade A, and UK (2013) with a grade A.

Data 5 shows two cases. First, the indication of inconsistency in grading the quality of the classroom action research theses and second, the aspects that have high levels of mistakes, that are the composition systematic of the research finding discussion. Data 6 shows that there is an indication of inconsistency in grading. Instead, the thesis with grade B has less mistakes than those with grade A.

The analysis towards the library research theses is applied on three samples of documents, they are written by: IHS (2011) passed with grade B, VWR (2011) passed with grade B+, and DAS (2012) passed with a grade A-.

Data 7 shows two cases. First, the indication of inconsistency in grading the quality of library research theses and second, a high level of mistakes in all aspects, and it goes to be fatal. Data 8 shows that there is an indication of inconsistency in grading and they have high levels of mistake. The inconsistency is shown by inaccurate measuring. The sample with grade $\mathrm{B}+$ has less mistakes than the sample with grade A+.

The analysis towards the development research theses is applied on three samples of documents, they are written by: I KMN (2011) passed with grade B+, RF (2012) passed with a grade A-, and TC (2012) passed with a grade A-.

Data 9 shows two cases. First, the indication of inconsistent grading to the quality of the development research theses, and second, a high level of mistakes in all aspects. Data 10 also shows that there is an indication of inconsistency in grading and they have high levels of mistake. The inconsistency is shown by inaccurate measuring. The sample with grade $\mathrm{B}+$ has less mistakes than the sample with grade A+. The high level mistakes of the composition aspect are the use of punctuation and word choice.

\section{DISCUSSION}

The main finding in this research, that has something to do with research variables, is on the aspect of the content and composition validities. The analysis shows that of the content validity level of the 15 theses as documents, there are 8 documents are grouped in the good category, 6 documents by mediocre category, and 1 document in the poor category. The analysis towards the validity level of the 15 documents shows that there are 10 documents are grouped in the good category, 4 documents by mediocre category and 1 document in the poor category.

From the analysis, finding on the content of the theses there were found the general patterns of the weak and the excellent. The theses content reflects the weakness in linking between the research variable and the theories. The research rationalization aims to the ability of systematical reasoning or how to synthesize the research finding to get valid concept. The excellent content is graded to these theses because of the empirical aspect done during the research. It is excellent because the researchers have the ability to get actual data and analyze those data accurately.

The relevant theories, that are used to verify the finding, are the patterns of mistake theory in a scientific work written by Guildford (in Asberg, 2009). Based on the theory, the weakness or the excellence of the theses content can be formed by the "halo effect" and "error of central tendency" patterns. The student orientation in supplying the data lets the other aspects ignored. Those indications are analogized as a "hallo" spectrum (the shaft of light that goes around the sun or moon). It means that preference to one aspect can take over the focus to the main purpose. The student orientation in getting actual data or accurate analysis will bend the focus of completing the main purpose of research, that is to systematically rationalize and communicate the research finding.

The analysis result of the composition aspect showed the general pattern of the weakness and the excellence in grammar or in rhetoric-scientific communication. The weakness of the composition aspect was in scientific communication, which was not reproductive. It means that, when unclear information is informed, the readers could potentially get different meanings from this information. The student's excellence in explaining the research finding was in standard form. The theses writing technique must refer to the UM's PPKI.

The relevant theory to verify the finding is the principle of scientific communication that is written by Suriasumantri (1990). The grammar used in scientific communication has two main elements, they are logical aspect and conformity with the rule of scientific work writing. The weakness of composition aspect in the theses lies in their systematic and clarity aspects (the scientific communication was not reproductive). It caused the lack of logical ability when the students write and express their scientific theses. The language excellence of the student in thesis document was in the using of Indonesian language standard form. It showed that the students are disciplined to obey the rules in science work writing.

The additional funding, that needs to discuss specifics, are three cases that have something to do with the student's preference to do the examination in the short term semester, the number of the selected theses topics and the inconsistency in grading the quality of the theses. According to the statistics, it has been predicted that, the preference will keep on continuing constantly.

The students prefer to complete their theses in the short term semester. The postponement was the reflection of the "academic procrastination" pattern at a time when they were busy in finishing their theses. The psychological aspects that cause the postponement, are: student's low motivation in doing a thesis, the hesitation to consistently come to the advisors to validate every part of the theses, unorganized working method, and interpersonal influence. 
The relevant theory to verify the findings is the concept of academic procrastination that was mentioned by Basco (2010). Among the nine general patterns of academic procrastination that were mentioned in the theory: five points are relevant to the research finding. The four points are: avoidance and laziness are relevant with lower motivation, downward counterfactuals are relevant to hesitant pattern, trivialization is relevant to the unorganized working pattern, and external attributions are relevant to interpersonal pattern.

The choice of the theses area was based on two cases, they were internal and external factors. The external factor is the advices given by the advisors. The internal factor is blocking and detouring original idea done by the classmates to influence others to change the chosen topic, and to influence the student's environments, that can drive them to change the chosen topic.

The relevant theory, that was used to verify the finding, was the Academic Self Conception (ASC) that was introduced by Brophy (2010). The theory that clarifies "the development of idea of 11-25 year old students (school and university students) can be measured by comparing someone with the surrounding friends at the same age", reinforced the finding that the propaganda of idea from other students is the main factor to influence the inconsistent behavior, in terms of changing the theses area.

The inconsistency in grading the quality of the theses was reflected by the ratio of the examination grade and the validation grade. The inconsistency patterns are: different grade for almost the same level of mistake, inappropriate grade for the mistake level, the same grade for the different level of mistake and imbalance grading intervals. These four patterns are the indicators of inaccurate theses quality grading.

The verification towards the grading inconsistency could be avoided if the examiners consequently refer the UM grading system, as defined in Paragraph 45 verse 1 and 9 Thesis Test / Final Task. Based on the verification, the various grading results of the thesis examination and the validity grading are caused by different scoring criterion. These validations focused on the validity of theses script grading. The thesis grading given by the examiner includes three aspects, they are: the validity of the script, the guidance process and the performance of the students during the examination.

\section{CONCLUSION AND SUGGESTION}

\section{A. Conclusion}

Based on the analysis, finding on the content and language composition aspects, it could be drawn the conclusions that have something to do with the validity level, weakness and the excellence of theses. The first conclusion, the content validity level of the 15 documents can be categorized as follows: 8 documents are in the good category, 6 documents are mediocre category and 1 document is in the poor category. The weakness of theses content is on the linking aspect and the rationalization of research findings. The excellence of the theses is on their empirical aspect. The second conclusion, the validity level of the composition aspect of the 15 documents tell that 10 documents are in the good category, 4 documents are in mediocre category, and one document is in the poor category. The weakness of composition aspect is in reproduction aspect. It means that unclear information is rewritten so, that the readers could potentially get a different meaning. The excellence is on the standard form aspect.

From the analysis, finding on the theses data recapitulation it was found that there are three additional findings that have something to do with the student's preference: the acceleration in doing theses, the selection of the theme and the inconsistency in grading the theses quality by the examiners. The first conclusion is that, the students prefer to do a thesis examination during the short-term, semester, because they believe that during that semester the administrative requirements are shortened, simplified and accelerated. The main factor of the preference is "procrastination" or psychological dimension that causes the postponement in finishing the theses. The second conclusion is that, the students can freely pick one of the varieties of research themes provided: non-experiment, classroom action, and experiment. The third conclusion is that, the inconsistency in grading of theses. Better thesis quality sometimes got lower grades than those which conveys worse quality. Different grades were given to the theses with the same quality, or, the grade given was not appropriate to the level of mistakes, and the grading level is imbalance.

\section{B. Suggestion}

Based on the conclusions of research findings, three suggestions are addressed in the lectures and the academic functionaries, especially in Geography Education Department, Faculty of Social Science Universitas Negeri Malang. It is suggested to the academic policy functionary that, it is necessary to supply with the "facility" as a counseling media for the students to prevent the indication of procrastination.

The lecturers as their advisors are suggested to extend to more detail, advise, in terms of the content and the writing technique, to adjust the thesis theme to the academic background academic of the advisors, to provide much more time to the student's need. And the examiners are suggested to improve the grading technique based on the academic grading system of the Geography Education Department and / or the university.

\section{ACKNOWLEDGMENT}

Our thanks to the Direktur Lembaga Penelitian dan Pengabdian Kepada Masyarakat (LP2M) Universitas Negeri Malang (UM), Direktorat Jenderal Pendidikan Tinggi, for the top seed research 2014/2015 financial aid given to us to examine this research project.

\section{REFERENCES}

[1] Asberg, Marie. 2009. "The Science of Grading Scales and the Experts' Opinion". The Paper Presentation on A Swedish Research Council Seminar, Stockholm, 5 November 2009.

[2] Basco, Monica Ramirez. 2010. "The Procrastinator's Guide to Getting Things Done". New York: The Guillford Press.

[3] Brophy, Jere. 2010. "Motivating Student to Learn". New York: Mc Graw Hill.

[4] Jurusan Pendidikan Geografi. 2008. "Pedoman Penulisan dan Proses Penyusunan Skripsi dan KKL". Malang: Jurusan 
Pendidikan Geografi, Fakultas Pendidikan dan Ilmu Pengetahuan Alam, Universitas Negeri Malang.

[5] Suriasumantri, Jujun S. 1990. "Filsafat Ilmu: Sebuah Pengantar Populer". Jakarta: Pustaka Sinar Harapan.

[6] Syafi'ie, Imam. 1984. "Analisis Kesalahan Berbahasa Indonesia dalam Menulis Mahasiswa Tiga IKIP Di Jawa”. Disertasi tidak diterbitkan. Malang: FPPS IKIP Malang.

[7] Universitas Negeri Malang. 2010. "Pedoman Pendidikan UM". Malang: Kementerian Pendidikan Nasional, Universitas Negeri Malang.

[8] Universitas Negeri Malang. 2010. "Pedoman Penulisan Karya Ilmiah”. Malang: Kementerian Pendidikan Nasional, Universitas Negeri Malang. 